ПІДПРИЄМНИЦТВО, ТОРГІВЛЯ ТА БІРЖОВА ДІЯЛЬНІСТЬ
ENTREPRENEURSHIP, TRADE AND EXCHANGE ACTIVITIES

Варченко Ольга, Артімонова Ірина, Герасименко Ірина, Качан Дмитро. Логістичне управління матеріально-технічним забезпеченням виробничої діяльності сільськогосподарських підприємств. Економічний дискурс. 2020. Випуск 3. С. 92-105.

DOI: https://doi.org/10.36742/2410-0919-2020-3-10

УДК 005.932:631.11

JEL Classification M11, Q12

\title{
Варченко Ольга
}

д.е.н., професор, проректор з наукової та інноваційної діяльності

Білоцерківський національний аграрний університет

м. Біла Церква, Україна

E-mail:Olga.Varchenko@btsau.edu.ua

ORCID: 0000-0002-9090-0605

Артімонова Ірина

канд. екон. наук, доцент, доцент кафедри фінансів, банківської справи та страхування

Білоцерківський національний аграрний університет

м. Біла Церква, Україна

E-mail:Artimonova.Iryna@btsau.edu.ua

ORCID: 0000-0003-1054-1356

Герасименко Ірина

канд. екон. наук, доцент, доцент кафедри фінансів, банківської справи та страхування

Білоцерківський національний аграрний університет

м. Біла Церква, Україна

E-mail:igerasymenko@btsau.edu.ua

ORCID: 0000-0002-7829-8009

\section{Качан Дмитро}

канд. екон. наук операційний директор

Newxel

м. Київ, Україна

E-mail: dmqachan@gmail.com

ORCID: 0000-0002-4826-2953

\section{ЛОГІСТИЧНЕ УПРАВЛІННЯ МАТЕРІАЛЬНО-ТЕХНІЧНИМ ЗАБЕЗПЕЧЕННЯМ ВИРОБНИЧОЇ ДІЯЛЬНОСТІ СІЛЬСЬКОГОСПОДАРСЬКИХ ПІДПРИЄМСТВ}


ЕКОНОМІЧНИЙ ДИСКУРС

Міжнародний науковий журнал

Buпуск 3. 2020
THE ECONOMIC DISCOURSE

International scientific journal

Issue 3. 2020

\section{Анотація}

Bcтуn. Сьогодні одним із найбільш складних та недостатньо вирішених питань $є$ оптимізація витрат у всіх ланках ланцюга поставок й вдосконалення управління матеріально-технічним забезпеченням виробничої діяльності сільськогосподарських підприємств. За умови трансфоормації економічних відносин, підвищення ефективності виробничої діяльності сільськогосподарських підприємств на принципах логістики можливо досягти через вибір оптимальної моделі організації процесу матеріально-технічного постачання підприємства.

Meтоди. Для досягнення поставлених завдань використовувалися різноманітні методи, такі як монографічний, графічний, статистичних групувань - для аналізу сучасного стану сільськогосподарського виробництва, визначення впливу факторів на рівень ефективності використання матеріально-технічної бази; вибірковий - для детального обстеження окремих сільськогосподарських товаровиробників щодо аналізу динаміки i структури матеріальних оборотних засобів та матеріальних витрат продукиії; абстрактно-логічний, розрахунково-конструктивний та оптимізаційний - при обгрунтуванні напрямів удосконалення організації матеріально-технічного постачання для сільськогосподарських товаровиробників.

Результати. З'ясовано, що останнім часом для більшості сільськогосподарських підприємств незалежно від розміру та напряму виробничої спеціалізації спостерігається суттєве зростання їх вартості, що обумовлено збільшенням вартості вхідних матеріальних ресурсів промислового і сільськогосподарського виробництва, а також методами оцінки надходження виробничих запасів. Встановлено, що зниження цих витрат на $10 \%$ дасть змогу збільшити прибуток підприємства на 10-20\%. Система управління ресурсним забезпеченням повинна орієнтуватися на забезпечення збалансованості наявних матеріальних ресурсів і потреби виробництва в них, а також створювати умови для своєчасного і якісного виконання виробничих планів, поліпшення логістики, зниження собівартості й підвищення споживчих властивостей готової продукиії.

Перспективи. 3 метою формування ефеективної логістичної системи управління виробничими запасами сільськогосподарських підприємств постає необхідність опрацювання типової моделі управління матеріальнотехнічним забезпеченням, орієнтованої на посилення контролю за процесом матеріально-технічного постачання і підвищення стійкості та збалансованого комплексного розвитку підприємств до змін у мінливому зовнішньому середовищі. Вдосконалення організації, планування і регулювання постачальницької діяльності призведе до досягнення оптимального забезпечення ресурсами відповідно до потреб виробництва сільськогосподарських підприємств.

Ключові слова: матеріально-технічні ресурси, товарно-матеріальні цінності, виробничий потенціал, виробничі запаси, збут, логістична кооперація.

\section{Вступ.}

Питання теорії та практики формування системи управління виробничими запасами активно розвивалися в останні 30 років минулого століття, у результаті чого було сформовано класичні методи та підходи. Використання розробленого інструментарію сучасною логістикою дозволяє сформувати логіку руху запасів та можливість моделювання їх оптимального значення, при якому повною мірою задовольняється виробнича потреба підприємства та мінімізуються витрати на їх формування та зберігання. Однак, незважаючи на численні моделі та методи управління запасами, більшість сільськогосподарських підприємств практично не використовують цей апарат, оскільки орієнтуються в основному на статистичні методи, які базуються на обробці складської та бухгалтерської звітності, доповнюючи її власними розробками у вигляді обгрунтованих норм і нормативів.

Важливим завданням логістики є оптимізація витрат у всіх ланках ланцюга поставок. У зв'язку із цим підвищується актуальність досліджень, які зорієнтовані на мінімізацію затрат щодо формування та зберігання виробничих запасів. Очевидно, що одним із найбільш складних та недостатньо досліджених питань $€$ управління виробничими запасами на сільськогосподарських підприємствах, для яких властивими є сезонність, значний розрив лагу між одержанням продукції та iï споживанням, залежність результатів від природно-кліматичних умов, виробничий процес пов'язаний із живими організмами - рослинами та тваринами та інші чинники, які визначаються специфіку процесу матеріально-технічного забезпечення господарської діяльності.

Водночас, стабільність макроекономічної ситуації та високий рівень розвитку інфраструктурного забезпечення зумовлюють нижчий рівень витрат на організацію логістики закупівель та їх частку у загальних витратах, а також стійкість інтеграції підприємства в економічний простір. Зазначимо, що вибір моделі організації процесу матеріально-технічного постачання 
підприємством здійснюється на основі аналізу економічного розвитку господарюючого суб'єкта (обсягів виробництва, спеціалізації, асортименту та якості продукції, яка виробляється, собівартості одиниці продукції, показників ефективності виробничо-фінансової діяльності, конкурентоспроможності підприємства та рівня залучення в інтеграційні та кооперативні зв'язки). Саме висока волантильність вищеперелічених показників зумовлює необхідність дослідження питань логістичного управління виробничими запасами на сільськогосподарських підприємствах.

\section{Аналіз останніх досліджень та публікацій.}

Вирішенню питання підвищення ефеективності управління матеріально-технічним забезпеченням виробничої діяльності підприємств присвячено наукові праці таких вітчизняних та зарубіжних учених: Д. Бауэрсокса, Я. Білоуська, Н. Бондаренко, О. Величка, О. Вишневецької, С. Дем'яненка, О. Захарчука, Д. Клосса, М. Кристофера, О. Лищенка, М. Михайлової, М. Могилової, І. Науменка, І. Охріменка, Б. Пасхавера, М. Сичова, В. Трегобчука, О. Ульянченка, Г. Черевка та інших фахівців. Проте, незважаючи на значний науковий інтерес до даної проблематики, питанню формування та функціонування ефеективних логістичних систем на сільськогосподарських підприємствах приділяється недостатньо уваги, що потребує подальших досліджень.

Мета.

Метою статті $€$ узагальнення підходів до організації матеріально-технічного забезпечення виробничої діяльності, ідентифікації його особливостей та розробки пропозицій щодо формування есективної системи управління процесами постачання на рівні сільськогосподарського підприємства.

\section{Методологія дослідження.}

У процесі проведення дослідження використовувалися такі методи та прийоми: монографічний, графічний, статистичних групувань - для аналізу сучасного стану сільськогосподарського виробництва, визначення впливу факторів на рівень ефективності використання матеріально-технічної бази; вибірковий - для детального обстеження окремих сільськогосподарських товаровиробників щодо аналізу динаміки і структури матеріальних оборотних засобів та матеріальних витрат продукції; абстрактно-логічний, розрахунковоконструктивний та оптимізаційний - при обґрунтуванні напрямів удосконалення організації матеріально-технічного постачання для сільськогосподарських товаровиробників.

При проведенні дослідження було використано наступний алгоритм. На першому етапі відібрано 52 сільськогосподарських підприємства, у яких здійснюється виробництво як продукції рослинництва, так і тваринництва, які сформували інформаційну базу для оцінки структури оборотних активів. Із цією метою із ф.1 фінансової звітності «Баланс» складено інформаційну базу для даного аналізу. Вивчення структури оборотних активів дозволило встановити залежність сільськогосподарських товаровиробників від формування окремих видів оборотних активів: виробничих запасів, незавершеного виробництва, готової продукції.

На наступному етапі використано ф.50 с.-г. економічної звітності за відібраними сільськогосподарськими підприємствами, на основі якої вивчено особливості фрормування матеріальних витрат у сільськогосподарському виробництві. У результаті проведених розрахунків стало можливим визначити специфіку формування оборотних активів та їх впливу на формування виробничої собівартості сільськогосподарської продукції.

Вивчення практичних підходів до організації процесу забазпечення матеріально-технічними ресурсами нами здійснено шляхом особистого відвідування сільськогосподарських підприємств та опитування менеджерів, що дозволило сформувати висновки щодо особливостей цього процесу у середовищі агробізнесу. 


\section{Результати.}

Організація постачальницької діяльності господарюючих суб'єктів аграрної економіки визначається особливостями сільського господарства як галузі суспільного виробництва та характеризується наступними чинниками: сезонністю виробництва; необхідністю формування значних обсягів окремих видів запасів (кормів та насіннєвого матеріалу), а також страхових запасів; значною тривалістю операційного циклу; обмеженістю у формуванні значних запасів в результаті понаднормативного псування (усушки та ін.) окремих видів запасів; необхідністю формування виробничих потужностей для зберігання виробничих запасів; волантильністю цін на продукцію сільського господарства; обмеженими фінансовими можливостями більшості сільгосптоваровиробників унаслідок недоступності до кредитних ресурсів та ін. [1-3].

Зазначимо, що нерозвиненість системи постачання сільськогосподарських підприємств істотно обмежує ефективність виробничої діяльності та зумовлює підвищення витрат обігу. В окремих наукових працях ототожнюють систему постачальницької діяльності господарюючих суб'єктів досліджуваної галузі із системою маркетингового забезпечення, де у якості основних чинників виділяють специфріку її організації: висока залежність ефективності сільськогосподарської діяльності від природно-кліматичних умов, рівня інтенсивності виробництва, гнучкість агротехнологій та адаптаційних можливостей товаровиробника; багатоукладність аграрного сектора, яка зумовлює певну складність системи взаємовідносин та загострення конкурентної боротьби між різними формами ведення сільськогосподарського виробництва; чітко виражену сезонність виробництва, неспівпадання часу виробництва сільськогосподарської продукції та ії̈ споживання; об'ємність значної частини сільськогосподарської продукції, короткі терміни ії зберігання без спеціальних умов та складність транспортування окремих її видів, що ускладнює вибір раціональної моделі переміщення та зберігання; тривалий період окупності інвестицій, особливо в умовах мінливості кон'юнктури ринку; існуючий диспаритет цін на сільськогосподарську продукцію та ресурси, які необхідні для її виробництва; низький рівень розвитку системи управління ризиками в сільському господарстві; недостатній рівень наукового супроводу маркетингової, логістичної діяльності в сільському господарстві та інші [4-6].

Узагальнення наукової літератури дозволило встановити, що теорія управління запасами, як і логістика в цілому, $є$ відносно молодою науковою сферою. Перші наукові дослідження з управління запасами з'явилися у кінці XIX ст., у 1887 р. було опубліковано книгу Маршала Кіркмана «Управління поставками для залізниці - закупівлі, розподіл». На початку двадцятого століття з'явилося цілий ряд наукових розробок щодо визначення оптимального обсягу замовлення: Ф. Харріса (1915 р.), К. Стефаник-Алмейєра (1927 р.), К. Андлера (1929 р.) і Р. Уїлсона (1934 р.). У подальшому розвиток теорії управління запасами у якості наукової дисципліни відбувся із середини 50-х років двадцятого століття.

Починаючи із 1970-х рр., розпочався наступний етап розвитку теорії управління запасами, який передбачає інтеграцію різних логістичних процесів. У цей період розроблено концепцію інтеграції ланок та елементів ланцюгів поставок, яка була представлена у працях Д. Бауерсокса, Р. Баллоу, Д. Клосса, М. Кристофера, Д. Ламберта, Дж. Стока, Д. Уотерса [7-11]. Саме цей період став початком активного вивчення та використання аналітичних моделей і методів управління запасами, а також використання сучасних інформаційних технологій, таких як: системи MRP, MRPII, $\mathrm{ERP}$, концепції QR «оперативного реагування», JIT «точно-у-час». Однак, незважаючи на велику кількість наукових праць як зарубіжних, так й вітчизняних дослідників, окремі питання в логістичному управлінні виробничими запасами залишаються відкритими.

У зв'язку з тим, що вивчення моделей може стати окремим дослідженням, більш детально розглянемо лише ті підходи, які можуть бути використаними на практиці. Вважаємо, що до таких моделей можна віднести ті, які наводяться в найбільш відомих виданнях. У результаті наукові праці можна поділити на чотири групи: дослідження в області логістики та управління ланцюгами поставок зарубіжних дослідників [7-11]; дослідження в області логістики та управління ланцюгами 
поставок українських науковців [12-14] та ін.; дослідження з логістики та менеджменту, у яких описано моделі та методи управління запасами, які використовуються при вирішенні задач постачання матеріальними ресурсами підприємств [15-17] та ін.; спеціальні роботи з теорії управління запасами $[18 ; 19]$.

Організація процесу постачання виробничої діяльності сільськогосподарських підприємств пов'язана із формуванням та зберіганням оборотних засобів, склад і структура яких повинні забезпечувати виробництво в достатній кількості матеріальними ресурсами і одержання грошових коштів, а також - основних активів. У структурі матеріальних оборотних засобів сільськогосподарських підприємств найбільшу частку займає незавершене виробництво, що характеризує особливість виробничої діяльності господарств корпоративного сектору аграрної економіки (табл. 1).

Таблиця 1. Динаміка структури матеріальних оборотних засобів сільськогосподарських підприємств Черкаської області*

\begin{tabular}{|l|c|c|c|c|c|c|c|c|c|}
\hline \multirow{2}{*}{ Показники } & \multicolumn{9}{|c|}{ Роки } \\
\cline { 2 - 11 } & 2012 & 2013 & 2014 & 2015 & 2016 & 2017 & 2018 & 2012 p. & 2017 р. \\
\hline Сировина і матеріали & 7,6 & 7,8 & 7,2 & 9,5 & 18,9 & 16,2 & 14,4 & 6,8 & 1,8 \\
\hline Паливо & 10,1 & 11,1 & 11,2 & 9,1 & 7,4 & 8,3 & 9,8 & $-0,3$ & 1,5 \\
\hline Будівельні матеріали & 0,0 & 0,0 & 0,0 & 0,1 & 0,1 & 0,2 & 0,1 & 0,1 & $-0,1$ \\
\hline Запасні частини & 8,0 & 7,7 & 6,8 & 4,4 & 4,6 & 5,6 & 6,7 & $-1,3$ & 1,1 \\
\hline $\begin{array}{l}\text { Матеріали } \\
\text { сільськогосподарського } \\
\text { призначення }\end{array}$ & 12,2 & 12,1 & 12,3 & 10,3 & 10,1 & 9,8 & 10,9 & $-1,3$ & 1,1 \\
\hline $\begin{array}{l}\text { Малоцінні та швидкозношувані } \\
\text { предмети }\end{array}$ & 0,2 & 0,2 & 0,2 & 0,2 & 0,3 & 0,3 & 0,3 & 0,1 & 0 \\
\hline Незавершене виробництво & 47,8 & 46,3 & 47,4 & 55,9 & 43,5 & 46,1 & 41,9 & $-5,9$ & $-4,2$ \\
\hline Готова продукція & 13,6 & 14,0 & 14,0 & 10,4 & 14,2 & 12,2 & 15,0 & 1,4 & 2,8 \\
\hline Товари & 0,6 & 0,7 & 0,8 & 0,2 & 1,0 & 1,3 & 0,9 & 0,3 & $-0,4$ \\
\hline Всього & 100,0 & 100,0 & 100,0 & 100,0 & 100,0 & 100,0 & 100,0 & 0 & 0 \\
\hline
\end{tabular}

*Джерело: розраховано за даними ф. 1 Баланс фінансової звітності підприємств.

Дані таблиці 1 свідчать, що протягом досліджуваного періоду зростала частка сировини та матеріалів у структурі оборотних активів, визначених для аналізу сільськогосподарських підприємств Черкаської області, зокрема: мінеральних добрив, засобів захисту та насіння. При цьому знижувалася частка пального, запасних частин і матеріалів сільськогосподарського призначення. Значну частку займає позиція «незавершене виробництво», яка у 2018 р. становила 41,9\%, що зумовлено специфікою сільськогосподарського виробництва, зокрема, посіви озимих культур, закладення саджанців та виноградників.

На основі чинних положень формування собівартості сільськогосподарської продукції вартість використаних матеріальних оборотних засобів, використаних у виробничому процесі, відображається по відповідних статтях витрат. Оцінюючи структуру матеріальних витрат сільськогосподарської продукції у середньому за 52-ма відібраними господарствами Черкаської області, можемо відзначити, що найбільшу частку займають оплата послуг сторонніх організацій, корми та мінеральні добрива (табл. 2).

За даними таблиці 2 упродовж досліджуваного періоду спостерігається суттєве підвищення частки у структурі матеріальних витрат мінеральних добрив та оплати послуг і робіт, виконаних сторонніми організаціями. Насамперед, це пов'язано із тим, що нині популярним серед малих та середніх сільгосппідприємств $€$ залучення для виконання окремих агротехнологічних операцій сторонніх організацій. Це у свою чергу потребує розвитку ринку агротехнічних послуг і стимулювання розвитку цих операторів з метою посилення конкуренції між ними i, як наслідок, мотивації у них до підвищення якості робіт та доступності їх вартості. Очевидно, що в умовах 
підвищення цін на матеріальні ресурси, з одного боку, буде змінюватися їхня частка у структурі, однак, запровадження на рівні підприємств режиму ресурсозбереження дозволить оптимізувати ії на рівні нормативно обгрунтованих значень.

Таблиця 2. Динаміка структури матеріальних витрат продукції сільськогосподарських підприємств Черкаської області*

\begin{tabular}{|c|c|c|c|c|c|c|c|c|c|}
\hline \multirow{2}{*}{ Показники } & \multicolumn{7}{|c|}{ Роки } & \multicolumn{2}{|c|}{2018 р., в. п. до } \\
\hline & 2012 & 2013 & 2014 & 2015 & 2016 & 2017 & 2018 & 2012 p. & $2017 \mathrm{p}$. \\
\hline $\begin{array}{l}\text { Матеріальні витрати: } \\
\text { усього }\end{array}$ & 100,0 & 100,0 & 100,0 & 100,00 & 100,0 & 100,0 & 100,0 & 0 & 0 \\
\hline \multicolumn{10}{|l|}{ у тому числі } \\
\hline $\begin{array}{l}\text { насіння і посадковий } \\
\text { матеріал }\end{array}$ & 11,6 & 13,0 & 12,9 & 12,0 & 12,0 & 11,9 & 12,6 & 1 & 0,7 \\
\hline корми & 26,2 & 23,1 & 20,7 & 20,7 & 20,0 & 19,2 & 18,9 & $-7,3$ & $-0,3$ \\
\hline з них покупні & 13,2 & 11,3 & 9,9 & 8,7 & 8,7 & 9,0 & 10,2 & -3 & 1,2 \\
\hline $\begin{array}{l}\text { інша продукція сільського } \\
\text { господарства }\end{array}$ & 2,8 & 1,9 & 1,8 & 2,0 & 1,8 & 2,0 & 1,6 & 1,2 & $-0,4$ \\
\hline мінеральні добрива & 15,4 & 16,7 & 14,1 & 19,0 & 20,0 & 18,7 & 15,3 & $-0,1$ & 3,4 \\
\hline $\begin{array}{l}\text { пальне і мастильні } \\
\text { матеріали }\end{array}$ & 14,2 & 13,4 & 15,4 & 12,9 & 11,3 & 12,6 & 13,2 & -1 & 0,6 \\
\hline електроенергія & 2,3 & 2,2 & 1,9 & 1,5 & 1,6 & 1,3 & 1,4 & $-0,9$ & 0,1 \\
\hline паливо й енергія & 1,5 & 2,0 & 1,6 & 1,5 & 1,1 & 1,0 & 1,2 & $-0,3$ & 0,2 \\
\hline $\begin{array}{l}\text { запасні частини, ремонт і } \\
\text { будівельні матеріали для } \\
\text { ремонту } \\
\end{array}$ & 6,9 & 6,6 & 7,4 & 8,0 & 8,3 & 7,9 & 7,6 & 0,7 & $-0,3$ \\
\hline $\begin{array}{l}\text { оплата послуг і робіт, } \\
\text { виконаних сторонніми } \\
\text { організаціями, та інші } \\
\text { матеріальні витрати }\end{array}$ & 19,1 & 21,1 & 24,2 & 22,4 & 23,9 & 16,4 & 18,0 & $-1,1$ & 1,6 \\
\hline
\end{tabular}

*Джерело: розраховано за даними фрінансової звітності підприємств.

Найважливіша особливість сільського господарства полягає в тому, що в цій галузі спостерігається значний розрив між робочим часом і часом виробництва. Оборотні засоби в сільському господарстві авансуються на порівняно тривалий період часу. Велика тривалість і сповільненість кругообігу авансованої вартості зумовлюють те, що відтворення в сільському господарстві $\epsilon$ відносно тривалим процесом вирощування рослин і тварин, успішні результати якого великою мірою залежать від природного фактору. Збереження і постійне підвищення родючості ґрунту набуває в даному випадку вирішального значення.

Ще одна особливість кругообігу засобів у сільському господарстві пояснюється своєрідністю процесу накопичення виробничих запасів в циклі кругообігу і процесу нарощення витрат у виробничому циклі. Сезонний характер виробництва в галузі диктує необхідність одночасного накопичення і тривалого зберігання значних запасів насіння і кормів власного виробництва. Крім того, виникає потреба в сезонному накопиченні нафтопродуктів, запасних частин, мінеральних добрив та інших покупних товарно-матеріальних цінностей. У зв'язку з цим сільськогосподарським виробникам доводиться авансувати в значних розмірах оборотні кошти в початкову стадію кругообігу.

Сезонність виробництва призводить до нерівномірних затрат праці та коштів у виробничому процесі по місяцях і кварталах року. Цим пояснюється неоднакова потреба в оборотних коштах протягом першого півріччя, коли відбувається поступове наростання витрат в незавершеному виробництві, періоду масового виходу готової рослинницької продукції. При цьому оборотні кошти не тільки залучаються в оборот нерівномірно, але й нерівномірно вивільняються з нього.

Структура оборотних активів сільськогосподарських підприємств характеризується високою часткою виробничих запасів як частини оборотних активів підприємства, що знаходиться у сфері виробництва. Це може бути молодняк тварин і дорослі тварини на відгодівлі, насіння і посадкові 
матеріали, запасні частини і матеріали для ремонту, нафтопродукти, паливо, мінеральні добрива, агрохімікати та медикаменти, тара і тарні матеріали, малоцінні і швидкозношувані предмети і т. д. Виробничі запаси необхідні для забезпечення нормального ритму виробництва з урахуванням умов надходження матеріальних ресурсів на підприємство та їх використання.

Упродовж 2012-2018 pp. незалежно від напряму виробничої спеціалізації сільськогосподарських підприємств спостерігається суттєве зростання їх вартості. Дана обставина пояснюється збільшенням вартості вхідних матеріальних ресурсів промислового та сільськогосподарського виробництва, а також методами оцінки надходження виробничих запасів.

Оцінюючи показники ефективності використання виробничих запасів можемо констатувати, що найвищий рівень оборотності виробничих запасів спостерігається у тваринницьких сільськогосподарських підприємствах, який у 2018 р. становив 3,82, або за період аналізу знизився на 18,1 в. п. Водночас при вирощуванні однорічних і дворічних культур у сільськогосподарських підприємствах у 2018 р. найнижчий коефріцієнт оборотності становив 2,06, або не значно знизився (на 0,6 в. п.), порівняно із 2012 р., що зумовлено специфікою рослинницької галузі.

Подібна ситуація спостерігається і при виробництві змішаних видів продукції, де коефріцієнт оборотності склав 2,31 у 2018 р., або знизився за період аналізу на 30,2 в. п. Це можна пояснити тим, що у сільськогосподарських підприємствах зі змішаним товарним асортиментом поєднані рослинницька та тваринницька галузі, що відповідно вплинуло на зниження показників оборотності виробничих запасів. Уповільнення оборотності виробничих запасів зумовлено також специфікою їх формування, що передбачає створення виробничих запасів, зокрема, фонду насіннєвого, кормів.

Встановлено, що на сьогодні для більшості сільськогосподарських підприємств, особливо середніх, характерна наявність неефективної служби матеріально-технічного постачання, що негативно позначається на ефективності відтворення матеріально-технічної бази, передусім у частині виробничих запасів. Вирішення цієї проблеми можливе за допомогою формування системи управління ресурсним забезпеченням. Вона має бути зорієнтована на забезпечення збалансованості наявних матеріальних ресурсів і потреби виробництва в них, а також створювати умови для своєчасного виконання виробничих планів, зниження собівартості й поліпшення споживчих властивостей готової продукції.

Так, матеріально-технічне постачання (МТП), визначення можливих напрямків і реалізація обгрунтованих заходів щодо її вдосконалення в діяльності конкретного підприємства дадуть змогу забезпечити високу ефективність ведення господарської діяльності та поліпшення його фінансового стану.

Встановлено, що в даний час в процесі використання більшості методів та інструментів управління МТП підприємства не приділяється належної уваги обґрунтуванню складу і зв'язків між елементами системи управління МТП, що забезпечують її ефективне функціонування в умовах господарювання, що склалися, та реалізацію обраної стратегії розвитку підприємства.

Згідно 3 результатами дослідження досвіду фуннкціонування сільськогосподарських підприємств, втрати в системі матеріально-технічного постачання можуть досягати 30\% від витрат на організацію постачальницької діяльності. Передусім це зумовлено невисокою ефективністю організації та управління процесами ресурсного забезпечення. За нашими розрахунками, зниження цих витрат на 10\% дасть змогу забезпечити збільшення прибутку підприємства на 10-20\%.

Із метою формування системи управління виробничими запасами необхідно узагальнити теоретичний і методичний аналіз проблеми. Отже, постає необхідність опрацювання типової моделі системи управління МТП підприємства, орієнтованої на посилення контролю за процесом постачання і підвищення стійкості до змін у зовнішньому середовищі. Це дасть можливість підвищити ефрективність організації, планування і регулювання постачальницької діяльності, своєчасно виявляти ці проблеми і можливі шляхи їх вирішення.

На основі результатів, отриманих у процесі дослідження, нами обґрунтовано модель системи управління МТП сільськогосподарського підприємства (рис. 1). 
ЕКОНОМІЧНИЙ ДИСКУРС

Міжнародний науковий журнал

Bunyck 3. 2020
THE ECONOMIC DISCOURSE

International scientific journal

Issue 3. 2020

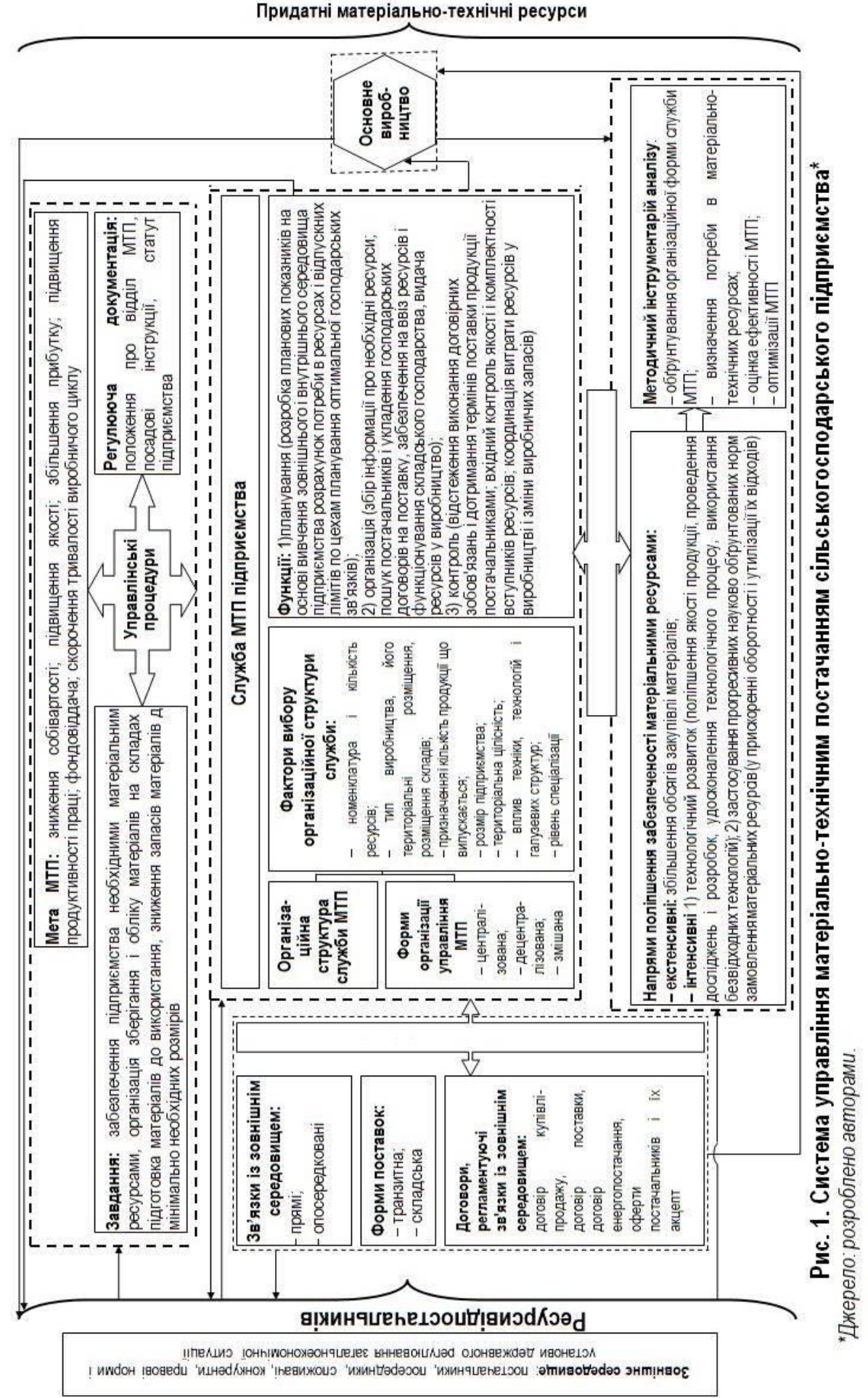


У запропонованій моделі забезпечується взаємозв'язок та взаємозумовленість в єдиному комплексі базових методичних елементів із організаційно-управлінськими інструментами та підходами; забезпечується відкритість спроектованої системи, а також передбачено комплекс інструментів матеріально-технічного обміну та нормативно-правових компонентів зв'язку підприємства із зовнішнім середовищем; визначено сферу використання (основне виробництво) i форми впливу (зниження матеріаломісткості продукції, зменшення кількості простоїв технічних засобів через невчасну поставку, скорочення часу виробництва, підвищення його ефективності та якості готової продукції), прояви ефектів у результаті оптимізації і вдосконалення управління матеріально-технічним забезпеченням.

Структура системи управління МТП об'єднує: організаційні чинники, які обумовлюють особливості побудови і функціонування оптимальної системи постачання виробничих ресурсів (територіальна цілісність, розмір підприємства, тип виробництва, номенклатура, обгрунтована величина ресурсів та ін.); управлінські завдання (цілі, завдання, функції МТП, нормативна база); методична база (економічний та економіко-математичний інструментарій (нормування, прогнозування, планування), який використовується в процесі визначення потреби, оптимізації запасів ресурсів, оцінки ефеективності їх використання та ін.); інструменти зв'язку із зовнішнім середовищем (форми поставок і умови укладення договорів, що забезпечують регулювання зв'язків системи із зовнішнім середовищем); основне виробництво (сфера прояву збалансованості МТП). Механізм прояву ефекту полягає в оптимізації часових параметрів виконання технологічних операцій, підвищенні ефективності виробництва та якості готової продукції, зниженні матеріаломісткості та простоїв обладнання через порушення термінів поставок, недодержання якісних параметрів, тощо).

Отже, застосування запропонованої нами моделі дозволить сільськогосподарським підприємствам підвищити ступінь наукового обґрунтування нормативної потреби в елементах матеріально-технічного постачання, забезпечити існуючу потребу із мінімальними витратами на придбання та зберігання товарно-матеріальних цінностей, а також сприятиме підвищенню координації заходів суб'єктів господарювання щодо вдосконалення організації, планування i регулювання матеріально-технічного забезпечення з метою досягнення збалансованості ресурсів 3 потребами виробництва.

Так, служба МТП сільськогосподарських підприємств, як керуючий елемент підсистеми, здійснює розробку технологій і методів в організації та менеджменту, а також виконує функції управління процесом постачання на всіх його етапах. Ця служба за допомогою використання ресурсних елементів (інформація, технічні засоби управління, кадри, фінанси) впливає на об'єкт управління (керовані підсистеми). Результатом управлінського впливу $є$ встановлення норм виробничих запасів, організація обліку руху матеріальних ресурсів і складання звітності, розробка проектів планів постачання, забезпечення ефективності матеріально-технічного забезпечення, а також моделювання ситуацій і прийняття управлінських рішень.

Виконання поставлених перед службою МТП підприємств завдань забезпечується у процесі реалізації нею базових функцій управління (планування, організації і контролю). До основних завдань постачання слід віднести: забезпечення виробничих підрозділів матеріально-технічними ресурсами, підготовка й укладання договорів на постачання, визначення річної потреби в ресурсах і нормативів виробничих запасів, облік видачі матеріалів виробничим підрозділам, підготовка звітності про рух матеріально-технічних ресурсів та ін.

Встановлено, що організаційна побудова служб постачання і перелік виконуваних ними функцій обумовлюються низкою факторів. Так, галузева належність підприємства і тип виробництва зумовлюють номенклатуру закуповуваної сировини, а також надійність поставок. Очевидно, що обсяги закупівель, а також чисельність співробітників служби постачання залежать від таких чинників, а саме: обсяги виробництва та товарного асортименту; спеціалізація і кооперування виробництва, що визначають необхідність створення спеціальних відділів кооперації та 
комплектації; місцерозташування підприємства і розміщення виробничих підрозділів; потужності складського господарства, наявність під'їзих шляхів, засобів зв'язку і транспорту.

Практика доводить, що вибір форми організації менеджменту матеріально-технічного постачання відбувається на етапі проектування системи управління і визначається на основі параметрів, які обумовлюють розподіл повноважень між працівниками. За нашою оцінкою, до ключових параметрів слід віднести: оперативність застосування повноважень; необхідний ступінь координації в роботі; рівень кваліфікації працівників; організаційно-правову фрорму підприємства; наявність ефективної системи обміну інформацією; ступінь самостійності підрозділів тощо.

Дослідження показали, що у більшості випадків виділяють централізовану, децентралізовану і змішану форми організації системи управління матеріально-технічним постачанням. Так, централізована система управління передбачає зосередження функцій в межах єдиної служби МТП. Вибір цієї форми доцільний за умови територіальної цілісності підприємства, а також вузької номенклатури споживаних матеріалів. Доведено, що в умовах територіального роз'єднання виробничих потужностей і самостійності підрозділів ефективнішою є децентралізована система управління, характерна для висококонцентрованих сільськогосподарських підприємств.

Оскільки система управління матеріально-технічним постачанням $€$ відкритою, то при ії проектуванні й обґрунтуванні методів та інструментів функціонування слід враховувати фрактори зовнішнього середовища і їх динаміку. За оцінкою білоруських науковців [20], до таких фракторів слід віднести: інтенсивність розвитку конкуренції, активність процесів глобалізації, частку інноваційної складової у сфері виробництва.

Сільськогосподарські підприємства формують економічні відносини із постачальниками матеріально-технічних ресурсів з урахуванням планованих змін у виробничій програмі. У практичній діяльності набув поширення прямий підхід (без участі спеціалізованого підрозділу чи відповідальної особи з постачання) і опосередкований (із їхньою участю) щодо формування економічних відносин.

Для проведення розрахунків і коригування нормативної потреби в матеріально-технічних ресурсах широко використовуються економіко-математичні моделі та методи оптимізаційного типу. За нашою оцінкою, це можна пояснити їх багатофуннкціональністю та високою вірогідністю одержуваних оцінок.

Виявлено, що від обірунтованого вибору методичного забезпечення (в т. ч. економікоматематичного інструментарію) працівниками відділу матеріально-технічного постачання для оцінювання майбутньої потреби в матеріально-технічних ресурсах і складання плану постачання підприємства визначальною мірою залежить можливість його практичної реалізації, рівень витрат на постачання і результативність виробництва в цілому.

Завищення планованих обсягів постачання призведе до утворення наднормативних запасів, підвищення витрат на зберігання, вивільнення з обігу частини грошових коштів. Визначення потреби в матеріально-технічних ресурсах у меншому обсязі загрожуватиме порушеннями ритмічності роботи, заміною одних матеріалів іншими, зокрема менш якісними. Це може спричинити погіршення споживчих властивостей продукції, а також підвищення її собівартості.

Виявлено, що дрібним сільгоспвиробникам не вдається самостійно організувати логістичне забезпечення свого бізнесу, внаслідок чого багато процесів організовуються нераціонально, збільшуючи витрати. Для малих господарств корпоративного сектору аграрної економіки вважаємо за доцільне створити інформаційний додаток до веб-сайту районного та обласного управління агропромислового розвитку, на якому розмістити інформацію про рівень оптово-відпускних цін і величину товарної партії на вхідні матеріальні ресурси, а також про юридичну адресу постачальника та способи розрахунку. Подібний підхід можна використати і на веб-сайті регіональних відділень державного Фонду підтримки фермерських господарств.

Однак пріоритетним напрямом удосконалення організації матеріально-технічного постачання можна розглядати розвиток кооперативних форм взаємовідносин при забезпеченні малих сільськогосподарських підприємств вхідними матеріальними ресурсами, а також при збуті 
продукції. Як свідчить аналіз діяльності вищезазначених суб'єктів агробізнесу, використання неформальної кооперації є менш ефективним порівняно з фрормальною унаслідок здійснення роботи без оподаткування і відсутності можливостей отримання державної підтримки.

За результатами опитування фахівців менеджменту малих суб'єктів агробізнесу Черкаської області було встановлено, що розвиток формальних кооперативних відносин знаходиться на низькому рівні. Проте значна частина опитаних відзначили їх необхідність та висловили готовність до кооперації за різними напрямами діяльності. Так, підприємці виділили п'ять основних напрямів спеціалізації для кооперування, які наведено нами в порядку зниження їх значимості: реалізація продукції, закупівля матеріально-технічних ресурсів; інфоорматизація, зберігання, переробка, транспортування. Отже, нині сільськогосподарські товаровиробники відчувають потребу в логістичній кооперації.

\section{Висновки і перспективи.}

У процесі обірунтування та розроблення пропозицій щодо удосконалення організаційної структури управління сільськогосподарським підприємством нами було детально вивчено такі питання: структура відділу МТП, модель управління та зв'язків відділу з іншими підрозділами, нормативна та методична база, цілі і завдання МТП на підприємстві, враховано основних постачальників ресурсів та ї місцезнаходження, вимоги підприємства до них, особливості формування економічних відносин тощо. Для чіткого уявлення про специфіку матеріального забезпечення в умовах діяльності підприємства важливо визначити невикористані резерви для підвищення ефективності постачання, а також систематизувати невирішені проблеми, що було забезпечено на основі аналізу сильних і слабких сторін постачання підприємства, його можливостей і загроз негативного впливу чинників зовнішнього середовища.

Отже, практична реалізація запропонованої моделі системи управління МТП підприємства сприятиме підвищенню ефективності організації, планування і регулювання матеріально-технічного забезпечення підприємства, у т. ч. за рахунок оптимізації матеріальних потоків (розмірів замовлень і запасів), підвищення ступеня узгодженості постачання і виробництва за термінами та обсягами матеріальних ресурсів, оперативного аналізу й вироблення координаційних дій у системі ресурсного забезпечення та ін.

Запропонована модель системи управління матеріально-технічним забезпеченням підприємства дозволить підвищити ступінь наукового обгрунтування нормативної потреби в елементах матеріально-технічного постачання, забезпечити повністю існуючу потребу із мінімальними витратами на їх придбання та зберігання, а також сприятиме підвищенню координації заходів суб'єктів господарювання щодо вдосконалення організації, планування і регулювання матеріально-технічного забезпечення з метою досягнення оптимального забезпечення ресурсами 3 урахуванням потреб виробництва.

Для дрібних сільгоспвиробників доцільно створити інформаційний додаток до сайту районного та обласного управління агропромислового розвитку, на якому розміщувати інформацію про рівень оптово-відпускних цін і величину товарної партії на вхідні матеріальні ресурси, а також юридичну адресу постачальника та способи розрахунку. Крім того, пріоритетним напрямом удосконалення організації матеріально-технічного постачання для цієї групи товаровиробників $\epsilon$ розвиток кооперативних форм.

Перспективою подальших наукових досліджень $€$ проведення аналітичної оцінки ефективності використання матеріально-технічної бази сільськогосподарськими підприємствами за сучасних умов господарювання.

\section{Список використаних джерел}

1. Пилипів Н. І, Борисовський М. І. Поняття і сутність товарно-виробничих запасів. Економічний аналіз. 2013. Вип. 12. Ч. 3. С. 303-306. [in Ukr.]

2. Бондаренко Н. М. Сутність та класифікація виробничих запасів на підприемстві. Вісник 
Чернігівського державного технологічного університету. 2014. № 4. С. 273-281.

3. Лищенко О. Г., Сердюк Є. М. Управління виробничими запасами: обліково-аналітичне забезпечення. URL : http://www.economy.nayka.com.ua/pdf/11_2018/53.pdf._(дата звернення : 12.03.2020).

4. Овчарик 3. Д. Економічна та технічна класифікація виробничих запасів у сільськогосподарських підприємствах. URL :https://www.pdaa.edu.ua/sites/default/files/nppdaa/5.3/213.pdf.(дата звернення : 16.03.2020).

5. Перебийніс В.І., Перебийніс О.В. Агропродовольчий комплекс: логістичні засади формування і функціонування. Науковий вісник Полтавського університету споживчої кооперації України. 2006. № 1. С. 7 12.

6. Гуторов О.І., Прозорова Н.В., Прозоров Р.Г. Формування логістичних систем в сільському господарстві: монографія. Харк. нац. аграр. ун-т ім. В.В. Докучаєва. Х.: Цифррова друкарня № 1. 2013. 259 с.

7. Бауэрсокс Д., Клосс Д. Логистика: интегрированная цепь поставок. М.: Олимп-Бизнес, 2010. 640 с.

8. Кристофер М. Логистика и управление цепями поставок ; пер. с англ. СПб.: Питер. 2004. 316 с.

9. Сток Дж. Р., Ламберт Д.М. Стратегическое управление логистикой. М.: ИНФРА - М. 2005. 757 с.

10. Уотерс Д. Логистика. Управление цепью поставок. М.: ЮНИТИ-ДАНА, 2003. 503 с.

11. Ballou R.Y. Business Logistics Management. 3 ed. Upper Saddle River. N.Y. PrenticeHall. Inc, 1992. 681

p.

12. Варченко О.М., Даниленко А.С. Логістика: теорія і практика: навч. посібник. К. : Хай-Тек Прес. 2010. $408 \mathrm{c}$.

13. Перебийніс В.І., Дроботя Я.А. Логістичне управління запасами на підприємствах: монограффія. Полтава : ПУЕТ. 2012. 279 с.

14. Дроботя Я.А. Досвід логістичного управління запасами в сільському господарстві. Вісник ХНАУ. 2010. № 11. С. 211-221.

15. Величко О.П., Лисенко І.М. Логістичний менеджмент операцій в системі ресурсного забезпечення аграрного виробництва. Економічний простір: Збірник наукових праць. 2009. № 29. С. 150-158.

16. Григорьев М.Н., Долгов А.П., Уваров С.А. Управление запасами в логистике: методы, модели, информационные технологии. С.-Петерб. гос. ун-т экономики и финансов. СПб.: Бизнес-пресса. 2006. 358 с.

17. Степаненко Т.О. Інтегроване управління матеріальними ресурсами підприємства. Стратегія економічного розвитку України. 2014. № 35. С. 132-139.

18. Сумець О.М., Назарян М.М., Федоренко М.М. Управління матеріальними запасами - ключовий аспект логістичної діяльності сучасного підприємства: монографія. Харків. нац. техн. ун-т сіл. госп-ва ім. П. Василенка, Харків. ін-т упр. Харків : Міськдрук. 2014. 255 с.

19. Швець Ю.А. Логістичні методи управління матеріальними запасами підприємства: сутність, роль та особливості впровадження. Вісник економіки транспорту і промисловості. 2017. № 58. С. 217-225.

20. Дашкевич Е. А. О совершенствовании механизма материально-технического обеспечения предприятий Республики Беларусь. Труды Белорусского государственного технологического университета. Экономика и управление. Минск. 2008. № 1. С. 40-44.

Статтю отримано: 01.06.2020 / Рецензування 15.07.2020 / Прийнято до друку: 20.09.2020

\section{Olga Varchenko}

Dr. Sc. (in Economics), Professor, Vice-Rector for Science and Innovation

Department of Finance, Banking and Insurance

Bila Tserkva National Agrarian University

Bila Tserkva, Ukraine

E-mail:Olga.Varchenko@btsau.edu.ua

ORCID: 0000-0002-9090-0605

Iryna Artimonova

Ph.D. (in Economics), Associate Professor, Associate Professor

Department of Finance, Banking and Insurance

Bila Tserkva National Agrarian University

Bila Tserkva, Ukraine

E-mail: Artimonova.Iryna@btsau.edu.ua

ORCID: 0000-0003-1054-1356 


\author{
Iryna Herasymenko \\ Ph.D. (in Economics), Associate Professor, Associate Professor \\ Department of Finance, Banking and Insurance \\ Bila Tserkva National Agrarian University \\ Bila Tserkva, Ukraine \\ E-mail:igerasymenko@btsau.edu.ua \\ ORCID: 0000-0002-7829-8009 \\ Dmytro Kachan \\ Ph.D. (in Economics), Chief Operating Officer \\ Newxel \\ Kyiv, Ukraine \\ E-mail:dmqachan@gmail.com \\ ORCID: 0000-0002-4826-2953
}

\title{
LOGISTIC MANAGEMENT OF MATERIAL AND TECHNICAL SUPPORT OF PRODUCTION ACTIVITY OF AGRICULTURAL ENTERPRISES
}

\begin{abstract}
Introduction. Today, one of the most difficult and insufficiently resolved issues is cost optimization in all parts of the supply chain and improving the management of logistical support of agricultural enterprises. With the transformation of economic relations improving the efficiency of production activities of agricultural enterprises on the principles of logistics can be achieved by choosing the optimal model of organization of the process of material and technical supply of the enterprise.

Methods. Various methods such as monographic, graphic and statistical groupings are used to accomplish these tasks - to analyze the current state of agricultural production, to determine the influence of factors on the level of efficiency of use of material and technical base; selective - for a detailed survey of individual agricultural producers on the analysis of the dynamics and structure of material working capital and material costs of production; abstract-logical, calculation-constructive and optimization - at substantiation of directions of improvement of the organization of material and technical supply for agricultural producers.

Results. It has been found out that for most agricultural enterprises, regardless of the size and direction of production specialization a significant increase in their value have recently seen. This increase is caused by the increase in the cost of inputs of industrial and agricultural production, as well as the methods of estimating the production inventory. It also has been found that reducing these costs by $10 \%$ will increase the profit of the company by $10-20 \%$. Resource management system should focus on ensuring the balance of available material resources and production needs in them, as well as create conditions for timely and quality implementation of production plans, improving logistics, reducing costs and improving the consumer properties of finished products.

Discussion. In order to form an effective logistics system for managing agricultural enterprises' inventories, there is a need to develop a standard model of logistics management, focused on strengthening the control over the process of logistics and improving the sustainability and balanced complex development of enterprises to change in a changing external environment. Improving the organization, planning and regulation of supply activities will lead to the optimal provision of resources for the needs of agricultural enterprises.
\end{abstract}

Keywords: material and technical resources, inventory values, production potential, production inventories, sale, logistic cooperation.

\section{References}

1. Pylypiv, N.I, \& Borysovskyi, M.I. (2013). Poniattia i sutnist tovarno-vyrobnychykh zapasiv [The concept and essence of inventories]. Ekonomichnyi analiz [Economic analysis], 12, 303-306.

2. Bondarenko, N.M. (2014). Sutnist ta klasyfikatsiia vyrobnychykh zapasiv na pidpryiemstvi [The clutter is that classification of the alignment stocking at the receiving point]. Visnyk Chernihivskoho derzhavnoho tekhnolohichnoho universytetu [Bulletin of Chernihiv State Technological University], 4, 273-281. [in Ukr.]

3. Lyshchenko, O.H., \& Serdiuk, Ye.M. Upravlinnia vyrobnychymy zapasamy: oblikovo-analitychne zabezpechennia. Retrieved from http://www.economy.nayka.com.ua/pdf/11_2018/53.pdf

4. Ovcharyk, Z.D. Ekonomichna ta tekhnichna klasyfikatsiia vyrobnychykh zapasiv u silskohospodarskykh pidpryiemstvakh._Retrieved from https://www. pdaa.edu.ua/sites/default/files/nppdaa/5.3/213.pdf. 
5. Perebyinis, V.I., \& Perebyinis, O.V. (2006). Ahroprodovolchyi kompleks: lohistychni zasady formuvannia i funktsionuvannia [Agro-food complex: logistical bases of formation and functioning]. Naukovyi visnyk Poltavskoho universytetu spozhyvchoi kooperatsii Ukrainy [Scientific Bulletin of the Poltava University of Consumer Cooperation of Ukraine], 1, 7-12. [in Ukr.]

6. Hutorov, O.I., Prozorova, N.V., Prozorov, R.H. (2013). Formuvannia lohistychnykh system v silskomu hospodarstvi: monohrafiia [Formation of logistics systems in agriculture: monograph]. Khark. nats. ahrar. un-t im. V.V. Dokuchaieva. Kh.: Tsyfrova drukarnia № 1, 259.

7. . Bauersoks, D., Kloss, D. (2010). Logistika: integrirovannaya tsep postavok [Logistics: integrated supply chain]. Moscow: Olimp-Biznes.

8. Kristofer, M. (2004). Logistika i upravleniye tsepyami postavok [Logistics and Supply Chain Management]. SPb.: Piter.

9. Stok, Dzh. R., \& Lambert, D.M. (2005). Strategicheskoye upravleniye logistikoy [Strategic logistics management]. Moscow: INFRA - M.

10. Uoters, D. (2003). Logistika. Upravleniye tsepyu postavok [Logistics. Supply chain management]. Moscow: YuNITI-DANA.

11. Ballou, R.Y. (1992). Business Logistics Management. 3 ed. Upper Saddle River. N.Y. PrenticeHall. Inc.

12. Varchenko, O.M., \& Danylenko, A.S. (2010). Lohistyka: teoriia i praktyka: navch. posibnyk [Logistics: theory and practice: nav. posibnik.]. Kyiv: Khai-Tek Pres.

13. Perebyinis, V.I., \& Drobotia, Ya.A. (2012). Lohistychne upravlinnia zapasamy na pidpryiemstvakh: monohrafiia [Logistic management of inventories in enterprises: monograph]. Poltava : PUET.

14. Drobotia, Ya.A. (2010). Dosvid lohistychnoho upravlinnia zapasamy v silskomu hospodarstvi [Experience in logistics management of stocks in agriculture]. Visnyk KhNAU [KhNAU Bulletin], 11, 211-221. [in Ukr.]

15. Velychko, O.P., \& Lysenko, I.M. (2009). Lohistychnyi menedzhment operatsii v systemi resursnoho zabezpechennia ahrarnoho vyrobnytstva [Logistic management of operations in the system of resource provision of agricultural production]. Ekonomichnyi prostir: Zbirnyk naukovykh prats [Economic Space: Collection of Scientific Papers], 29, 150-158.

16. Hryhorev, M.N., Dolhov, A.P., \& Uvarov, S.A. (2006). Upravleniye zapasami v logistike: metody, modeli, informatsionnyye tekhnologii [Inventory management in logistics: methods, models, information technology]. S.Peterb. hos. un-t ekonomiki i finansov. SPb.: Biznes-pressa.

17. Stepanenko, T.O. (2014). Intehrovane upravlinnia materialnymy resursamy pidpryiemstva [Intehrovane upravlinnia materialnymy resourcesamy pidpryiemstva]. Stratehiia ekonomichnoho rozvytku Ukrainy [Stratehiia ekonomichnoho rozvytku Ukrainy], 35, 132-139. [in Ukr.]

18. Sumets, O.M., Nazarian, M.M., \& Fedorenko, M.M. (2014). Upravlinnia materialnymy zapasamy kliuchovyi aspekt lohistychnoi diialnosti suchasnoho pidpryiemstva: monohrafiia [Inventory management is a key aspect of modern enterprise logistics: monograph]. Kharkiv. nats. tekhn. un-t sil. hosp-va im. P. Vasylenka [Kharkiv. nat. tech. un-t forces. the owner in it. P. Vasylenka], Kharkiv. in-t upr. Kharkiv : Miskdruk.

19. Shvets, Yu.A. (2017). Lohistychni metody upravlinnia materialnymy zapasamy pidpryiemstva: sutnist, rol ta osoblyvosti vprovadzhennia [Logistic methods of inventory management: the nature, role and features of implementation]. Visnyk ekonomiky transportu i promyslovosti [Bulletin of Economics of Transport and Industry], 58, 217-225. [in Ukr.]

20. Dashkevych, E.A. (2008). O sovershenstvovanii mekhanizma material'no-tekhnicheskogo obespecheniya predpriyatiy Respubliki Belarus [On improving the mechanism of material and technical support for enterprises of the Republic of Belarus]. Trudy Belorusskogo gosudarstvennogo tekhnologicheskogo universiteta. Ekonomika $i$ upravleniye [Proceedings of the Belarusian State Technological University. Economics and Management], 1, 40-44.

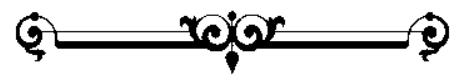

